\title{
Effect of Soil Amendments with Rice-Husk Waste on Pythium Wet Rots of Melon Citrullus lanatus L (Sync.vulgaris) (Rice Husks Waste and Cattle Manure Are Sound Alternatives to Fungicide)
}

\author{
S. Muhammad ${ }^{1}$, and K. Shehu ${ }^{2}$
}

\begin{abstract}
Pasteurised soil in Pots, was infected with cultures of Pythium aphanidermatum and impregnated with rice husk waste. Another set was made and allowed to stand for $0,5,10,15$, and 20 days before planting the seeds of Melon, the control experiment was infected soil without amendments. Pythium wet rot that developed was less severe in the seedlings with rice husk amendment and increase in days before planting also influenced the reduction in severity of the disease. The number of leaves developed was highest in the group of seedlings whose seed were sown after 20 days of amendment. Rice husk amendment was found to be more effective in reducing the severity of the diseases. In the control the whole seedlings collapsed 7 days after germination. These method(s) may leave a cleaner and unpolluted environment and also compliment other efforts in the intergrated management approach to plant disease problem.
\end{abstract}

Keywords-Rice husks waste, Cattle manure, fungicide, Pythium wet rot

\section{INTRODUCTION}

Melon Citrullus lanatus L (Sync.vulgaris): Family Cucurbitaceae Melon (egusi) appears to be the most neglected tropical vegetable in agricultural research. This apparent neglect is is not unconnected with the fact that melon is closely linked with traditional intercropping systems where over $92 \%$ ofb this vegetable is inter-cropped in Nigeria (Okigbo, 1987). Melon is a creeping annual plant. It possess hairy stems deeply divided and triangular-shaped leaves and small yellow flowers. The large circular fruit is made up of white fleshy material inside which are embedded small flat seeds. According to research conducted at IITA (1984) egusi melon grows fast after planting. It flowers 30-35 days after planting,by 60 days after planting the leaves start dying while the mature fruits and vines liter the soil surface. Fruits can be harvested from 80-100 days by collecting the fruits which are later cut and fermented to get out seeds.

\footnotetext{
${ }^{1}$ Department of Biological Sciences, Usmanu Danfodiyo University, Sokoto, Nigeria

${ }^{2}$ Department of Biological Sciences, Federal University, Birnin Kebbi, Nigeria
}

Melon is a popular food stuff in Nigeria, Ghana Zaire and many parts of Africa. In Nigeria over 360,00 hecters were grown with egusi melon during the 1980-81 growing season (Echo,1984).Little is known about the productive potentials of egusi melon grown in either alone or inter-cropped.Melon dehulled seeds are indespensable in most types of Nigerian soup for its high nutritional values. It consists of dry matter $91.92 \%$ crude protein, $34.43 \%$ true protein, $4.37 \%$ crude fibre, digestabl crude protein 31.38 , and nitrogen free extract $3.85 \%$. It is consequently low in carbohydrates (5\%) but contain fair amount of minerals (Oyenuga, 1978). In traditional medicine egusi leaves are believed to possess some therapeutical properties and are commonly used for this purposes in south eastern Nigeria. In united states the genus Colocynthis is source of colocynth which is sold as a violet purgatives (Ikeorgu,1984).

No mosaic or bacterial diseases have been reported on melon probably because of the scanty work so far done on this crop.However melon is susceptable to many fungal diseases which include root diseases pre and post emergence damping-off (wet-rot) caused primarily by Pythium species,Powdery mildews caused by Pseudoperenospora cubensis, and Anthracnose caused by Collectotrichum lagenarium (Summer, 1983). The surprising thing is that despite the importance of leguminous tree crops in Nigerian diets and economy, their production has remained in the hands of resource-poor, subsistence farmers whose traditional methods do not sufficiently meet the challenges of our fast developing community.

Evidence has shown that various types of Agricultural wastes suppressed different soil bone plant diseases( Vaughn et al 1954 ). Sun (1989) reported the use of organic matter to control streptomyces scabies known to cause potato scab. Green organic matter incorporated in the planting trench increased general microbial activities which antagonizes the streptomyces.

On the other hand, the use of chemicals to control soil bone plant diseases in present day Nigeria is costly and may not be at the reach of peasant farmers. The increasing awareness about pollution problems and of toxic chemicals in our food-chain impel us to use non-chemical methods to solve our plant disease problems. The research reported here is aimed at evaluating a non chemical method (s) of controlling Pythium wet rot of 
Melon caused by Pythium aphanidermatum.

\section{MATERIALS AND METHODS}

The pathogens (Pythium aphanidermatum.) used in this study were isolated from diseased leaves of Melon as per method of ( Sun,1989). Several small sections 1-3 mm square were cut from the margin of the infected lesson of a leaf. These were then placed in absolute alcohol for 15-30 seconds. Sections were blotted dry on clean sterile paper towels after washing in three - changes of sterile water and were finally placed on potato dextrose Agar (PDA) and incubated for 24 - 48 hours at $28 \mathrm{oc}$. The growth of the colonies were recognized and the pure cultures were obtained by sub-culturing the pathogens from the mix-culture into another fresh PDA incubated for 24 72 hours at 280 . Sixty 5 - litre plastic buckets were filled with $5 \mathrm{~kg}$ pasteurized soil and arranged on a bench in green house at Biological garden, Usmanu Danfodiyo University, Sokoto. 3replicates were made for each pathogen. 3 - culture plates of each pathogen maintained on PDA were homogenized with 50 $\mathrm{ml}$ sterile water in a blender and suspensions were mixed thoroughly with $2.5 \mathrm{~cm}$ to $3.5 \mathrm{~cm}$ soil depth on each bucket to inoculate the soil. Each bucket was amended with $50 \mathrm{~g}$ Rice-husks and watered with $250 \mathrm{ml}$ daily. The replicates were allowed to stand for $0,5,10,15$ and 20 days respectively before planting the seeds of Melon at the same day. In order to determine the effectiveness of various amendments another sets were made and amended with cattle-manure and treated as above. There were additional replicates of bucket that do not contain pathogens to serve as control. 10 seeds were planted on each bucket and Seedlings were examine for foliar diseases at interval of 7,15 and 30 days after germination.

\section{EXPERIMENTAL DESIGN}

A completely randomised design (CRD) with three replications was used, that is the treatment were assigned completely at random so that each experimental unit has the same chance of receiving any treatment, however a computer statistical programme 'The SAS' was used to analysed the data. Six treatments namely 0 -day, 5 -days, 10 -days 15 -days 20 -days and control were used.The dependent variables were percentage diseased leaves, Average number of leaves and Average height of the seedlings taken at interval of 7,15 and 30 days. The data was analysed with analysis of variance (ANOVA) and where there were significant differences among treatments, means separations by Duncans Multiple Range Test was used to treat the significance.

\section{RESULTS AND Discussion}

The results obtained showed that suppression of Pythium damping-off in Melon caused by Pythium aphanidermatum was enhanced by increasing the time between soil amendments with rice-husks and planting (Tables 1 2). There was significant differences with respect to number of leaves at $7^{\text {th }}$ day of observations; and with respect to height of the seedlings at $7^{\text {th }}$ and $15^{\text {th }}$ day of different period of soil amendment with rice-husks, and in the control $85 \%$ compound leaves disease was recorded. (Table 1). Previously reports (Hardar, 1984, Baker,1974 and Muhammad 1997) showed similar results using composted liquorice, composted sewage sludge and cattle-manure in various plant respectively. Soil amended with rice husk was found to suppress Pythium damping-off in Melon at different degrees. Table 1 shows the effects of soil amendment with rice husk on seedling damping-off and growth and in Melon There were significant differences at $5 \%$ between the types of amendments. Soil amended with cattle manure and stood for 20 days before planting reduced the incidence from $85 \%$ and $80 \%$ in controls to $17 \%$ and $15 \%$ respectively at 30 DAG. Average number of compound leaves (ANCL) was also found to increase significantly at $5 \%$ between amendments. The largest ANCL of 24 was recorded in a 20 day amended soil 30 DAG and the maximum seedling length recorded was $24 \mathrm{~cm}$.

These results implied that rice husk might be useful as soil amendment to suppress Pythium damping-off of Melon and of other plants. An excellent result was recorded on soils amended for 20 days before planting in both rice-husks amendments. Although small proportion of rice husks are feed to domestic animals, a large amounts, however are been dumped away as wastes with no useful purpose.

Suppression of Pythium damping-off in Melon was found to be effective following the use of soil amendments withrice husk; Possibily due to the activity of microorganisms that developed with the amendments. Experience has shown that various types of agricultural wastes suppressed different soil bone plant diseases. Several reports show similar results using composted liquorice, wood residues and rice-husk amendments in various plant species (Hadar et al. 1984, Lumsden et al. 1983, and Muhammad 1998). Cassava peel wastes amendment was found to be effective in control of Pythium wet-rot of tomato in Sokoto (Muhammad and Manga 1997). Palti (1981) and Chen, and Hadar,. (1987). reported the use of organic matter to control Streptomyces scabies known to cause potato scab, like wise green organic matter incorporated in to the planting trench increased general microbial activities, which antagonize the Streptomyces. In all the periods of amendments carried out in the study the most favourable effect was observed on soil amended 20 days before planting possibly due to the fact that the organic wastes might have been degraded and hence made available for developing microorganisms that antagonised the pathogens. In a previous work, amendment of Chitin, Cellulose and Starch at $0.1 \% \mathrm{~W} / \mathrm{W}$ was found to reduce the population of Fusarium spp in sugar-cane soils. While Chitin at 5\% resulted in maximum inhibition of Fusarium spp by $80-90 \%$ after 1-4 weeks of amendment (Gupta, 1986).

The results obtained in the present study also imply that increased in time between soil amendments and planting enhanced suppression of the diseases. This also agreed with the findings of Mandelbaum and Hadar (1990) whose study on kinetics of microbial activity found to increase in the first 24 hours after nutrient amendment with cattle manure. The natural organic manure in form of, Rice-husks probably contains 
microbes which are likely to produce antibiotics, that have suppressive effects on the activities of the pathogen. Chet and Baker (1980) also reported that soils that are naturally injurious to R.solani contained a high natural population of Trichoderma harzianum. Organic manure is known to add nutrients to the soil thereby increasing the soil fertility and thus increasing the vigour of the plants growing in it and also making the plant less prone to infection by pathogens. Although there were significant differences when planting was done in 0 day after soil amendment compared with the control, with respect to percentage diseased compound leaves (\%DCL), but the incidence of the diseases was still very high. Moreover, 20 days after soil amendment, the nutrients in the compost could have been released into the soil and made available to plants, compared to planting made 5 days after amendments. Previous reports by (Hadar, et al 1984, Lumsden et al 1983, and Muhammad and Manga, 1997) also showed similar results using composted liquorice, composted sewage sludge and rice-husks in various plants respectively. Generally it can be said the the results observed have indicated that incidence of disease was less in seedlings raised in soils amended in the following order, sawdust, rice husk and cattle manure, respectively.

Increase in the number of days after amendment before planting also influenced the number of compound leaves produced and plant height attainment. The measurements were significant in the seedlings among the treatments. This may not be unconnected with the fact that leaf conditions are the primary indicators of health of a tree (Lenne and Jullian, 1994). Therefore, the healthier are condition of a tree is the larger the number of the leaves it can produce and hence the taller the seedlings would be expected to be. Organic waste is known to add nutrients to the soil thereby increasing the soil fertility, due to the cellulose decomposing microorganisms which might antagonise the pathogens and hence make the plant to grow healthy. Similar observation was reported in Saudi Arabia where thirty fungal species belonging to fifteen genera were identified as cellulose decomposing fungi that added nutrient to the soils (Bahkali and Khiyami, 1996).

The results obtained in this study showed that if disease control by soil amendments can be fully developed into field experiments, it will be helpful in the establishment of sustainable Agriculture in Nigeria and elsewhere, Rice huks wastes are economically and ecologically sound alternatives to pesticide. However further investigation are needed on how to apply the method in field experiment.

\section{CONCLUSION}

From the results obtained, it can be concluded that Soil amended with Rice husk and allowed to stand for 20 days prior to planting consistently controlled Pythium damping seedling damping off of Melon diseases, the number of compound leaves produced and taller seedlings were produced in these treatments.

\section{RECOMMENDATIONS}

1. Since plant pathologists have enough evidence against use of chemical control method, they have stressed the need to change the concept of "Pesticides" to "Pest control agents" Secondary microorganisms developed with the amendment serve as biocontrol agents, therefore, might be useful in the control of foliar fungal diseases of the tree species under study.

2. Since small proportion of rice husks are used as feedmill to domestic animals, and sawdust in generating energy for domestic uses, large amounts, however are dumped as wastes with little or no use. Therefore soils should be amended with such organic wastes 20 days before planting the seeds of the tree-species under study.

3. Further field studies are still needed on the mode of application of these methods and use. Attempts to develop alternative application technology to reduce the amount of organic matter needed. High ratios of compost-amendment to soil are needed to achieve suppressive ness to foliar pathogens in plants. Although this control system may be adaptable to high value greenhouse plants, it cannot be considered practical in this form for field crops where high amount of compost are economically impractical. Therefore the following methods are suggested for further trials

a. Seed Treatment: This is by soaking the seeds in solutions containing the said antagonistic microorganisms the seed are then re-dried before sowing.

b. Foliar application: A standard system of compost containing these antagonist with required mycelia water ration (mat:water ratio) can be sprayed on the infected foliar-parts

\section{REFERENCES}

[1] Baker, K. F. and R. J. Cook (1974), Biological control of plant pathogen Freeman and company. 433pp.

[2] Dalziel, (1957) The useful plants of west Tropical Africa Crown agents. $27 \mathrm{pp}$.

[3] F.A.O (1990) Provisional indicative world plan for Agricultural development. Vol. 2 F.A.O of the united nations Rome 672pp.

[4] Hadar, Y; Harma, G. E. and Taylor, A. C. (1984). Evaluation of Trichoderma koningii and T. harzianum from New York soils for biological control of seed rot caused by Pythiuum sp Phytopathology 74:106. http://dx.doi.org/10.1094/Phyto-74-106

[5] I.I T.A, (1990) International institute of Tropical Agriculture, Ibadan Nigeria Annual report for 1989

[6] Muhammad, S. and S. B. Manga. The effects of soil amendments with cassava peels on Pythium wet rot of tomato caused by Pythium aphanidermatum (EDSON). Fitz: The Beam Journal of Art and Sciences 1:160-165.

[7] Oladiran, A. O (1983). Studies on diseases of cowpeas (Vigna unguiculata). A Ph. D. Thesis in Department of Botany and Microbiology, University of Ibadan Nigeria p 23-27.

[8] Sellscho J.P.F. (1962). Cowpea, Vigna Unguiculata (L) Walp. Field Crop Abstracts 15 Review Article 249-266.

[9] Sun, S.K. (1989). Use of soil born diseases Taiwan Taichung District Agriculture Improvement Station No 16: 141-151.

[10] Vaughn E.K.; Robert A.N and Mellenthim W.M (1954). The influence of douglas Fir sawdust and certain fertilizer elements on incidence of red stele disease in straw-berry Phytopathology 44:601.

[11] Williams, R.J. (1973). Disease of Cowpea Vigna unguiculata (L). (Walp) in Nigeria. PANS 21 (3) 253-267. 


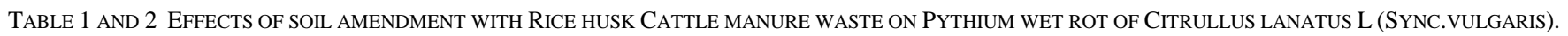

\begin{tabular}{|c|c|c|c|c|c|c|c|c|c|c|}
\hline \multirow[t]{2}{*}{$\begin{array}{l}\text { Types of } \\
\text { Amendments } \\
\text { (Organic } \\
\text { wastes) }\end{array}$} & \multirow[t]{2}{*}{$\begin{array}{l}\text { Level of } \\
\text { Treatments } \\
\qquad \text { (Days) }\end{array}$} & \multicolumn{3}{|c|}{$\begin{array}{l}\text { Percentage diseased rot leaves } \\
\text { Days after germination (DAG) }\end{array}$} & \multicolumn{3}{|c|}{$\begin{array}{l}\text { Average number of leaves } \\
\text { Days after germination (DAG) }\end{array}$} & \multicolumn{3}{|c|}{$\begin{array}{l}\text { Average height of the seedlings } \\
\text { (cm) Days after germination (DAG) }\end{array}$} \\
\hline & & 7 & 15 & 30 & 7 & 15 & 30 & 7 & 15 & 30 \\
\hline Control & & $62_{\mathrm{a}}$ & $65_{a}$ & $68 \mathrm{a}$ & $9_{\mathrm{c}}$ & $10_{\mathrm{c}}$ & $13_{\mathrm{c}}$ & $6_{\mathrm{e}}$ & $11_{\mathrm{d}}$ & $11_{\mathrm{e}}$ \\
\hline Rice husk & 0 day & $46_{b}$ & $45_{b}$ & $44_{b}$ & $8 \mathrm{c}$ & $10_{\mathrm{c}}$ & $12_{\mathrm{c}}$ & $7_{\text {ed }}$ & $14_{\mathrm{c}}$ & $18_{\mathrm{d}}$ \\
\hline Rice husk & 5 days & $42_{c}$ & $39 \mathrm{c}$ & $4_{\mathrm{e}}$ & $6_{\mathrm{c}}$ & $10_{\mathrm{c}}$ & $14_{\mathrm{c}}$ & $8 \mathrm{~d}$ & $14_{\mathrm{c}}$ & $20_{c}$ \\
\hline Rice husk & 10 days & $37_{d}$ & $36_{d}$ & $33_{\mathrm{c}}$ & $9_{\mathrm{b}}$ & $12_{b}$ & $17_{\mathrm{b}}$ & $10_{\mathrm{c}}$ & $15_{\mathrm{b}}$ & $21_{\mathrm{b}}$ \\
\hline Rice husk & 15 days & $22_{\mathrm{e}}$ & $21_{\mathrm{e}}$ & $19_{\mathrm{d}}$ & $11_{\mathrm{a}}$ & $15 \mathrm{a}$ & $17_{\mathrm{b}}$ & $11_{\mathrm{b}}$ & $17 \mathrm{a}$ & $22_{\mathrm{a}}$ \\
\hline Rice husk & 20 days & $22_{\mathrm{e}}$ & $20_{\mathrm{e}}$ & $19_{\mathrm{d}}$ & $11_{\mathrm{a}}$ & $15_{\mathrm{a}}$ & $19 \mathrm{a}$ & $13_{\mathrm{a}}$ & $17 \mathrm{a}$ & $20_{c}$ \\
\hline Control & & $55_{\mathrm{a}}$ & $55_{\mathrm{a}}$ & $60_{\mathrm{a}}$ & $9_{\mathrm{e}}$ & $11_{\mathrm{d}}$ & $16_{\mathrm{c}}$ & $9_{\mathrm{b}}$ & $\begin{array}{l}16_{c} \\
16_{b}\end{array}$ & $21_{\mathrm{d}}$ \\
\hline Cattle manure & 0 day & $53_{\mathrm{b}}$ & $53_{\mathrm{a}}$ & $51_{\mathrm{b}}$ & $9 \mathrm{e}$ & $11_{\mathrm{d}}$ & $17_{\mathrm{c}}$ & $9_{\mathrm{b}}$ & $\begin{array}{c}c \\
17_{b}\end{array}$ & $20_{\mathrm{e}}$ \\
\hline Cattle manure & 5 days & $51_{\mathrm{c}}$ & $48_{b}$ & $45_{\mathrm{c}}$ & $11_{\mathrm{d}}$ & $14_{c}$ & $18_{\mathrm{b}}$ & $10_{\mathrm{b}}$ & $\begin{array}{c}c \\
19_{b}\end{array}$ & $23_{\mathrm{c}}$ \\
\hline Cattle manure & 10 days & $40_{\mathrm{d}}$ & $33_{\mathrm{c}}$ & $28_{\mathrm{d}}$ & $12_{\mathrm{c}}$ & $14_{c}$ & $19_{\mathrm{b}}$ & $11_{\mathrm{b}}$ & $\mathrm{a}$ & $23_{\mathrm{c}}$ \\
\hline Cattle manure & 15 days & $22_{\mathrm{e}}$ & $19_{\mathrm{d}}$ & $18_{\mathrm{e}}$ & $14_{\mathrm{b}}$ & $17_{\mathrm{b}}$ & $22_{a}$ & $18 \mathrm{a}$ & $21_{\mathrm{a}}$ & $24_{b}$ \\
\hline Cattle manure & 20 days & $20_{\mathrm{f}}$ & $18_{\mathrm{d}}$ & $17_{\mathrm{e}}$ & $16_{a}$ & $18_{\mathrm{a}}$ & $22_{\mathrm{a}}$ & $15_{\mathrm{a}}$ & $16_{\mathrm{c}}$ & $25_{\mathrm{a}}$ \\
\hline
\end{tabular}

Means followed by the same letter(s) are not significantly different at 5\% probability according to Duncans Multiple Range Test (DMRT) 